\title{
BENDING STRENGTH AND STIFFNESS OF STRUCTURAL LAMINATED VENEER LUMBER MANUFACTURED FROM FAST-GROWING ARGENTINEAN EUCALYPTUS GRANDIS
}

\author{
Saviana J. ${ }^{1}$, Sosa Zitto M.A², Piter J.C ${ }^{3}$.
}

\begin{abstract}
The present paper reports the results of an investigation regarding the determination of bending strength and stiffness in specimens of laminated veneer lumber (LVL) manufactured from Argentinean Eucalyptus grandis and tested edgewise according to European standards. For this purpose an empirical research project with one sample containing 44 specimens with nominal sizes of $24.3 \mathrm{~mm}$ in width, $100 \mathrm{~mm}$ in depth and $2.44 \mathrm{~m}$ in length was carried out. The characteristic strength value was $74 \%$ and $118 \%$ higher, respectively, than those adopted by Argentinean standards for the best strength class of sawn and glued laminated timber of the same species. It was similar to that reported for LVL of Norway spruce and lower than that published for LVL made from Uruguayan Eucalyptus grandis even though in the latter case the reported value was not obtained according to European standards. The modulus of elasticity mean value was $22 \%$ and $14 \%$ higher, respectively, than those adopted by Argentinean standards for the best strength class of sawn and glued laminated timber of the same species. Modulus of elasticity also exhibited a mean value $22 \%$ and $53 \%$ higher, respectively, than those published for LVL manufactured from Norway spruce and Uruguayan Eucalyptus grandis. A relatively low variation of results was found for both strength $(\mathrm{COV}=9 \%)$ and modulus of elasticity $(\mathrm{COV}=10 \%)$ and the particularly high stiffness/density relation previously published for sawn timber of this Argentinean deciduous species was confirmed by the results of this study. The coefficient of determination $\left(\mathrm{R}^{2}\right)$ between density and modulus of elasticity was equal to 0.67 whereas $\mathrm{R}^{2}$ reached 0.37 between modulus of elasticity and strength and 0.19 between density and strength.
\end{abstract}

Keywords: Laminated veneer lumber, Eucalyptus grandis, strength, stiffnes

\section{INTRODUCTION}

Previous studies showed that both sawn and glued laminated timber of Argentinean Eucalyptus grandis, which is one of the most important renewable species cultivated in Argentina (INTA1995), may advantageously perform as structural material (Piter et al. 2004b and 2007). Moreover, the ratio of modulus of elasticity to density of this species (Piter et al. 2004c) is higher than the same ratio for all strength classes for deciduous species according to European standards, which may be an important advantage for structural purposes. Plywood and other wood-based panels are also made from Argentinean Eucalyptus grandis but laminated veneer lumber (hereafter LVL) was not produced up to the present from this species and, consequently, no systematic studies regarding its mechanical properties have been carried out.

\footnotetext{
${ }^{1}$ Ingénieur du Bois. Depto. de Ing. Civil, Facultad Regional Concepción del Uruguay, Universidad Tecnológica Nacional. (E3264BTD) Concepción del Uruguay, Entre Ríos, Argentina. email:julien.perspectives@orange.fr

${ }^{2}$ Investigador del Grupo de Estudio de Maderas. GEMA. Depto. de Ing. Civil, Facultad Regional Concepción del Uruguay, Universidad Tecnológica Nacional. (E3264BTD) Concepción del Uruguay, Entre Ríos, Argentina. 
However, due to the increasing importance of this material in many countries, physical and mechanical property results were published for LVL manufactured from softwood as well as hardwood of different species and provenance (Benites 2004, Ranta-Maunus 1995, Shukla and Kamdem 2007). The reported values for LVL are normally higher than those obtained for other traditional wooden products, which may be explained by the fact that large defects can be avoided when logs are cut into thin veneers and these are laid and glued parallel to the grain (Ranta-Maunus 1995).

LVL is a new high strength wood-based material which is considered by modern design rules as those established in Eurocode 5 (EN 1995-1-1 2005). For structural purposes, its more important physical and mechanical properties may also be determined according to the criterion adopted by European standards (EN 14374 2005, EN 408 2004, prEN 14358 2006) which allows to obtain comparable results. In addition to its very good mechanical behaviour, LVL exhibits other advantages common to all wooden materials such as those related to environmental aspects (Shukla and Kamdem 2007).

The reasons mentioned before encouraged the design of a research project aimed at studying the bending strength and stiffness of LVL manufactured from Argentinean Eucalyptus grandis. Since non-destructive methods have increased their importance for determining the mechanical properties of sawn timber and wooden products (Glos 1995, Ilic 2001, Piter et al. 2004a, Beall 2007), the study of the correlation between the main physical and mechanical properties was included in the project mentioned above.

The aim of this paper is to present and discuss the results of an investigation regarding the determination of characteristic strength and stiffness values in specimens of LVL manufactured from fast-growing Argentinean Eucalyptus grandis and tested in bending edgewise according to European standards. Further aim of this paper is to compare these results with those reported for both sawn and glued laminated timber of the same species and with those published for LVL of different species and provenance. Additionally, the relationship between modulus of elasticity and strength and that between density and mechanical properties is presented.

\section{MATERIAL AND METHODS}

The material was prepared by a company which normally manufactures plywood from the same species as a standard product. Since LVL is a product close to plywood and the company has produced the latter material for many years for domestic demand and also for the European market, international requirements related to material quality and process control were fulfilled. Logs of Eucalyptus grandis grown in Virasoro, Corrientes, were used. This is one of the main provenance for this species in Argentina (INTA 1995). A total of 320 logs with a nominal length of $2.44 \mathrm{~m}$ were rotary peeled into veneers which were then visually examined and those free of biological affections and large defects were accepted. With the purpose of selecting material representing the whole range of quality normally used for the fabrication of plywood, no other grading process was applied to this material and veneers with a nominal thickness of $2.7 \mathrm{~mm}$ were randomly selected for the project. After drying, 11 sheets with nominal sizes of $2.44 \mathrm{~m}$ in length, $1.22 \mathrm{~m}$ in width and $24.3 \mathrm{~mm}$ in thickness were made by gluing with phenol formaldehyde adhesive and hot pressing 9 veneers which were laid with the grain running parallel. With the aim of studying the mechanical properties of this material without the influence of veneer joints, each finished sheet was then cut parallel to its length in such a way that pieces for testing in bending edgewise with nominal sizes of $24.3 \mathrm{~mm}$ in width, $100 \mathrm{~mm}$ in depth and $2.44 \mathrm{~m}$ in length were obtained. Finally, 44 of them were randomly selected for this project and each specimen was cut to a length of 20 times its depth. 
After transporting the material to the laboratory, it was conditioned in a room at $20^{\circ} \mathrm{C}$ temperature and $65 \%$ relative humidity. Actual dimensions and measurements for each test piece were taken after conditioning in normal climate, and made to an accuracy of $1 \%$. Static tests in bending were carried out according to the procedures of the European standard EN 408 (2004). All specimens were placed symmetrically on the supports and loaded edgewise at one-third span length over a span of 18 times the depth (Fig 1). Lateral restraint was provided to prevent buckling in such a way that it permitted the pieces to deflect without significant frictional resistance. A loading machine Shimadzu UH 1000kN, capable of applying loads with adequate rate of movement of the loading-head and accuracy of $1 \%$ was used. Deformations were registered at the centre of the span and at the centre of the tension zone for determining the global modulus of elasticity. One extensometer, capable of registering $0.01 \mathrm{~mm}$, was used. Moisture content $(\mathrm{mc})$ and density $(\rho)$ were calculated according to the procedures of EN 322 (1993) and EN 323 (1993), respectively, using a clear full cross section taken from the test specimen after the static test.

Bending strength $\left(\mathrm{f}_{\mathrm{m}}\right)$ and global modulus of elasticity $\left(\mathrm{E}_{\mathrm{m}}\right)$ were calculated for each specimen by using the standard solution. Since European standards establish that strength results obtained on LVL specimens with a depth ranging between $100 \mathrm{~mm}$ and $300 \mathrm{~mm}$ shall be adjusted to a reference depth of $300 \mathrm{~mm}$, test results were adjusted $\left(\mathrm{f}_{\mathrm{m}, \mathrm{corr}}\right)$ by following the procedures of EN 14374 (2005). After adjusting the test results, the characteristic strength value $\left(\mathrm{f}_{\mathrm{m}, \mathrm{k}}\right)$ was obtained according to the criterion adopted by prEN 14358 (2006).

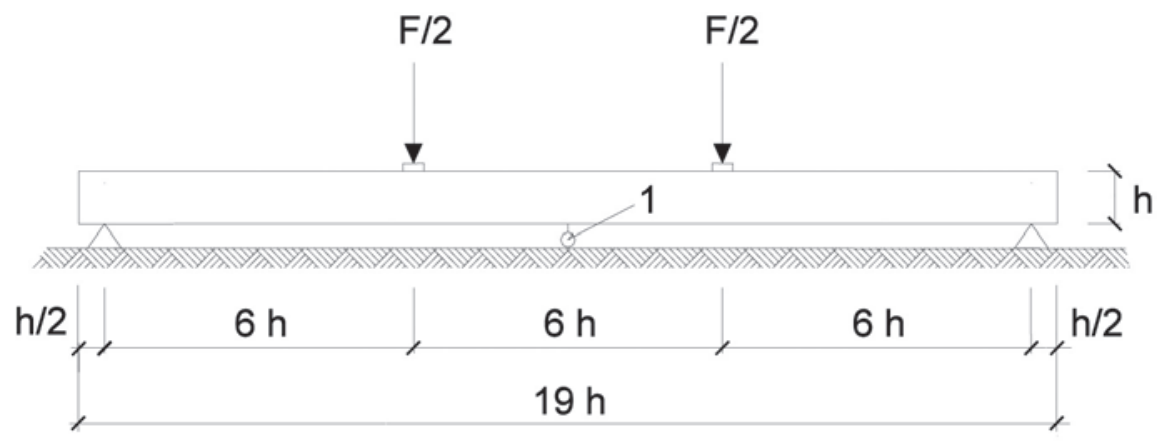

Fig. 1: Test arrangement

1: Extensometer for registering the deformation.

\section{RESULTS AND DISCUSSION}

Moisture content ranged between $5.9 \%$ and $8.4 \%$ with a mean value of $7.5 \%$. Width presented a mean value of $24.2 \mathrm{~mm}$ with a coefficient of variation $(\mathrm{COV})$ of $2 \%$ whereas the corresponding values for depth were $101.0 \mathrm{~mm}$ and $1 \%$. The main results for mechanical and density properties corresponding to the whole sample $(n=44)$, obtained with the moisture content mentioned before, are summarised in table 1 . 
The results found in this research for mechanical and density properties may be compared with values previously reported for sawn timber of the same species. The strength mean value presented in Table $1\left(f_{\mathrm{m}}=70.6 \mathrm{~N} / \mathrm{mm}^{2}\right)$ is $61 \%$ higher than that of $43.9 \mathrm{~N} / \mathrm{mm}^{2}$ informed by Piter et al. $(2004 \mathrm{c})$ for a test series enclosing 50 beams with a nominal depth equal to that adopted for the specimens of the present project and tested in bending according to European standards. The modulus of elasticity mean value found in this research $\left(17147 \mathrm{~N} / \mathrm{mm}^{2}\right)$ is $45 \%$ higher than that of $11800 \mathrm{~N} / \mathrm{mm}^{2}$ reported by Piter et al. (2004c) in the test series mentioned before. The mean value presented in table 1 for density (753 $\mathrm{kg} / \mathrm{m}^{3}$ ) is $39 \%$ greater than that of $540 \mathrm{~kg} / \mathrm{m}^{3}$ (at $12 \% \mathrm{mc}$ ) reported by Piter et al. (2004c) for a test series with 349 specimens of sawn timber of the same species.

Table 1: Main results for mechanical and density properties corresponding to the 44 specimens of LVL tested in bending edgewise

(1) corrected to a reference depth of $300 \mathrm{~mm}$ according to EN 14374 (2005); (2) obtained according to the criterion of prEN 14358 (2006).

\begin{tabular}{|c|c|c|c|c|}
\hline & $\begin{array}{c}\mathrm{f}_{\mathrm{m}} \\
\left(\mathrm{N} / \mathrm{mm}^{2}\right) \\
\mathrm{n}=44\end{array}$ & $\begin{array}{c}\mathrm{f}_{\mathrm{m}, \text { corr }}\left({ }^{(1)}\right. \\
\left(\mathrm{N} / \mathrm{mm}^{2}\right) \\
\mathrm{n}=44\end{array}$ & $\begin{array}{c}\mathrm{E}_{\mathrm{m}} \\
\left(\mathrm{N} / \mathrm{mm}^{2}\right) \\
\mathrm{n}=44\end{array}$ & $\begin{array}{c}\rho \\
\left(\mathrm{kg} / \mathrm{m}^{3}\right) \\
\mathrm{n}=44\end{array}$ \\
\hline Min & 58.8 & 51.2 & 13284 & 657 \\
\hline Mean & 70.6 & 61.6 & 17147 & 753 \\
\hline Max & 85.3 & 74.4 & 19563 & 829 \\
\hline $\operatorname{COV}(\%)$ & 9 & 9 & 10 & 5 \\
\hline Characteristic & & $\mathrm{f}_{\mathrm{m}, \mathrm{k}}=52.2^{(2)}$ & & \\
\hline
\end{tabular}

Table 1 also shows the strength results corrected to a reference depth of $300 \mathrm{~mm}\left(\mathrm{f}_{\mathrm{m}, \mathrm{corr}}\right)$ according to EN 14374 (2005) and the corresponding characteristic value $\left(\mathrm{f}_{\mathrm{m}, \mathrm{k}}=52.2 \mathrm{~N} / \mathrm{mm}^{2}\right)$ which was calculated according to prEN 14358 (2006). Since the characteristic strength value is a main parameter for the safety format adopted by modern limit state codes as Eurocode 5 (2005), technical and economical reasons account for the convenience of comparing the characteristic strength value found in this research with those adopted by Argentinean standards for sawn and glued laminated timber of the same species. To make the comparison easier, the characteristic values adopted by the Argentinean standards IRAM 9662-2 (2006) and IRAM 9660-1 (2006) for the best strength grade of sawn timber and glued laminated timber, respectively, and the corresponding reference conditions, are presented in table 2 . The value of $\mathrm{f}_{\mathrm{m}, \mathrm{k}}$ presented in table 1 is $74 \%$ higher than that of $30 \mathrm{~N} / \mathrm{mm}^{2}$ adopted by IRAM 9662-2 (2006) and $118 \%$ higher than that of $24 \mathrm{~N} / \mathrm{mm}^{2}$ adopted by IRAM 9660-1 (2006). Since the design of bending members is often controlled by serviceability limitations such as deflection and vibration, the mean value obtained in this research for modulus of elasticity was also compared with those adopted by Argentinean standards for both sawn and glued laminated timber of the same species. The modulus of elasticity mean value exhibited in table $1\left(17147 \mathrm{~N} / \mathrm{mm}^{2}\right)$ is $22 \%$ higher than that of $14000 \mathrm{~N} / \mathrm{mm}^{2}$ adopted by IRAM 9662-2 (2006) for the best strength class of sawn timber and $14 \%$ higher than that of $15000 \mathrm{~N} / \mathrm{mm}^{2}$ adopted by IRAM 9660-1 (2006) for the best strength class of glued laminated timber. These results show that the stiffness of LVL was somewhat higher but the characteristic strength value was about twice that of both sawn and glued laminated timber of the same species. However, when analysing the results and specially the characteristic strength value obtained in this research, it is necessary to take into account some particular features of this project. 
One of them is connected with the relatively low statistical base of the sampling plan, which was previously described in Material and Methods. The other feature is related to the absence of veneer joints in the test specimens which may have increased the results obtained for strength and stiffness in comparison with those corresponding to specimens manufactured with jointed veneers.

Table 2: Bending strength and stiffness values adopted by Argentinean standards for the best strength grade of sawn and glued laminated timber of Argentinean Eucalyptus grandis

(1) Adjusted to a reference depth of $150 \mathrm{~mm}$ for solid-sawn timber and to a reference depth of 600 $\mathrm{mm}$ for glued laminated timber, in line with the criterion adopted by European standards; (2) adjusted to a reference moisture content of $12 \%$, in line with the criterion adopted by European standards;

\begin{tabular}{|c|c|c|c|}
\hline Material & $\begin{array}{c}\text { Argentinean } \\
\text { standard }\end{array}$ & $\begin{array}{c}\text { Characteristic } \\
\text { strength value }^{(1)}\end{array}$ & $\begin{array}{c}\text { Mean value of } \\
\text { modulus of elasticity }\end{array}$ \\
\hline Solid-sawn lumber & IRAM 9662-2(2006) & 30 & 14000 \\
\hline Glued laminated timber & IRAM 9660-1 (2006) & 24 & 15000 \\
\hline
\end{tabular}

No values for mechanical and density properties of LVL manufactured from Argentinean Eucalyptus grandis were published but results obtained on specimens of LVL made from softwood as well as hardwood of different provenance were informed. Ranta-Maunus (1995) reports a characteristic value of $51.0 \mathrm{~N} / \mathrm{mm}^{2}$ with COV values less than $10 \%$ for strength of LVL manufactured from Norway spruce, which were determined according to European standards. These reported results are similar to those found in this research (Table 1). However, the mean values presented in Table 1 for modulus of elasticity and density are $22 \%$ and $45 \%$ higher, respectively, than those of $14000 \mathrm{~N} / \mathrm{mm}^{2}$ and $520 \mathrm{~kg} /$ $\mathrm{m}^{3}$ (at $10 \% \mathrm{mc}$ ) reported by Ranta-Maunus (1995) for LVL made from Norway spruce. Benites (2004) informs mean values of $96.4 \mathrm{~N} / \mathrm{mm}^{2}$ and $11200 \mathrm{~N} / \mathrm{mm}^{2}$ for strength and modulus of elasticity of LVL manufactured from Uruguayan Eucalyptus grandis, respectively. These values were obtained from a test series carried out on $25 \mathrm{~mm} \times 25 \mathrm{~mm} \times 400 \mathrm{~mm}$ specimens loaded at the centre of the span. The mean value published by Benites (2004) for strength is $37 \%$ higher than that presented in Table 1. Contrarily, the mean value presented in Table 1 for modulus of elasticity is $53 \%$ greater than that informed by Benites (2004). Nevertheless, considering that the results reported by Benites (2004) were not obtained according to European standards, a more fitting comparison between the strength and stiffness values of Uruguayan Eucalyptus grandis and the corresponding results obtained in this research should take into account the influence of both the test arrangement and specimen sizes on results. The mean value presented in Table 1 for density, which was calculated at an average mc of $7.5 \%$, is $11 \%$ higher than that of $680 \mathrm{~kg} / \mathrm{m}^{3}$ reported by Benites (2004) for Uruguayan Eucalyptus grandis although in the last case the average mc reached $11.8 \%$.

It is interesting to observe that the relation between the mean values of modulus of elasticity and density found in this research $\left(17147 \mathrm{~N} / \mathrm{mm}^{2} / 753 \mathrm{~kg} / \mathrm{m}^{3}\right)$ is only slightly lower than that reported by Ranta-Maunus (1995) for LVL manufactured from Norway spruce $\left(14000 \mathrm{~N} / \mathrm{mm}^{2} / 520 \mathrm{~kg} / \mathrm{m}^{3}\right)$. These results are congruent with those previously published for sawn and glued laminated timber of Argentinean Eucalyptus grandis (Piter et al. 2004c, 2007) and confirm a particularly high relation of stiffness to density for LVL made from this deciduous species. Piter et al. (2004c) report a higher stiffness/density relation than the same ratio for all strength classes for deciduous species according to European standards. Moreover, the reported relation is only slightly lower than that adopted by European standards for poplar and coniferous species. This particularity, together with the relatively low dispersion of strength (COV $=9 \%)$ and stiffness $(\mathrm{COV}=10 \%)$ results, may be considered an important advantage of the tested material for structural purposes. 
Figure 2, shows the relationship between global modulus of elasticity and strength for the 44 specimens. The coefficient of determination $\left(\mathrm{R}^{2}=0.37\right)$ was equal to that published by Piter et al. (2004b) for a test series with 50 sawn beams tested in bending according to European standards which presented the same nominal depth as that adopted for the specimens of the present project.

A

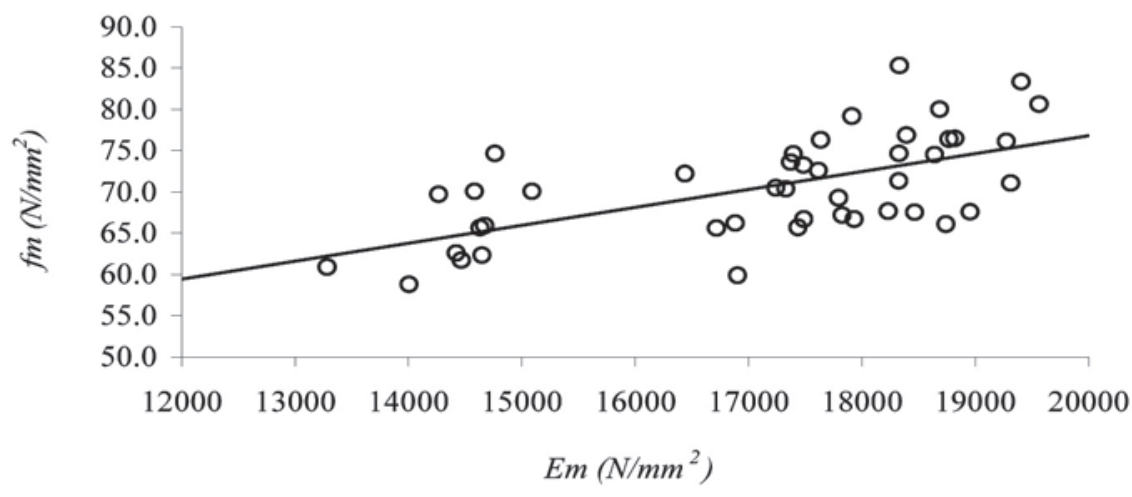

B

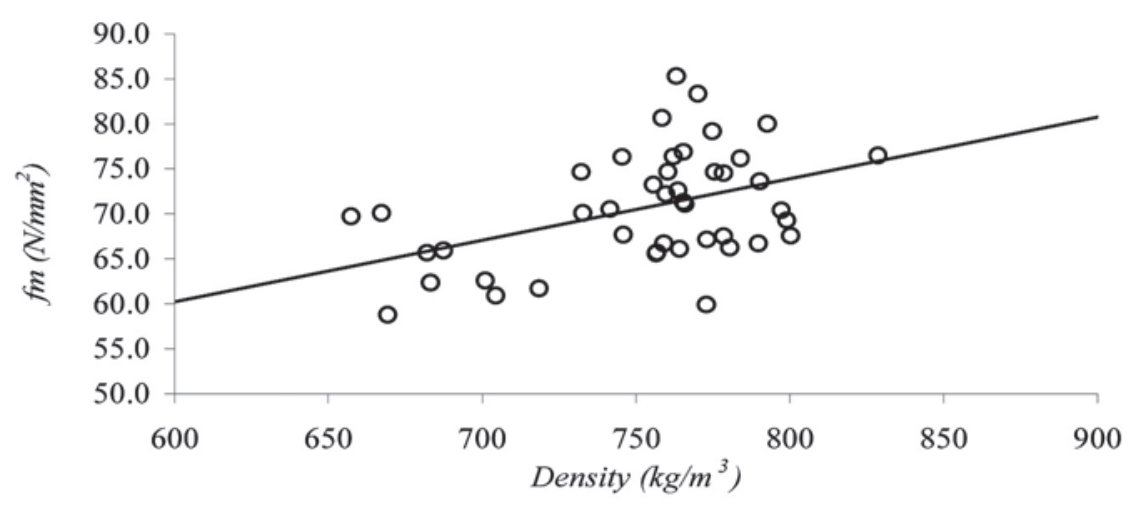

$\mathrm{C}$

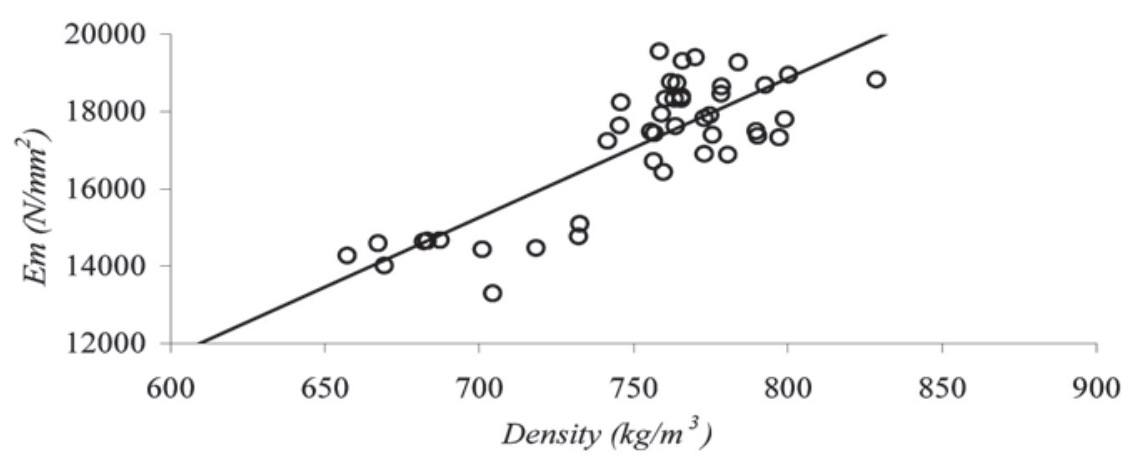

Fig. 2: Relationship between: A) global modulus of elasticity and strength; B) density and strength; C) density and global modulus of elasticity.

Coefficients of determination: A) $\mathrm{R}^{2}=0.37$; B) $\mathrm{R}^{2}=0.19$; C) $\mathrm{R}^{2}=0.67$. Linear regression equations: A) $\mathrm{f}_{\mathrm{m}}=0.0022 \mathrm{E}_{\mathrm{m}}+33.3$; B) $\mathrm{f}_{\mathrm{m}}=0.0685 \rho+19.1$; C) $\mathrm{E}_{\mathrm{m}}=36.03 \rho+9968$. 
The values of strength and modulus of elasticity are displayed in relation to density in Figures $2 \mathrm{~B}$ and $2 \mathrm{C}$, respectively, for the whole sample. The correlation between density and strength $\left(\mathrm{R}^{2}=0.19\right)$ was similar to that reported by Piter et al. (2004b) for a test series enclosing 349 specimens of sawn timber of the same species. Figure $2 \mathrm{C}$ shows that the correlation between density global modulus of elasticity was higher than that found between the variables displayed in the two previous figures. The $\mathrm{R}^{2}$ value found in this case means that density explained about $67 \%$ of the variability of global modulus of elasticity by itself. This result encourages further studies aimed at exploring the relation between density and modulus of elasticity, on the base of research project supported by a larger statistical base than that adopted in this study, regarding two goals. The first one related to the possibility of producing different qualities of LVL manufactured from this species by grading the veneers according to the density. The second one connected with the use of non-destructive methods for determining the mechanical properties of this product.

\section{CONCLUSIONS}

The characteristic strength value obtained in this research was $74 \%$ higher than that adopted by the Argentinean standard IRAM 9662-2 (2006) for the best strength class of sawn timber of Argentinean Eucalyptus grandis and it was $118 \%$ higher than that adopted by IRAM 9660-1 (2006) for the best strength class of glued laminated timber of the same species. It was similar to that reported for LVL manufactured from Norway spruce. The mean value obtained for strength was lower than that reported for LVL manufactured from Uruguayan Eucalyptus grandis, although it is necessary to consider that the reported mean value was not obtained by following the procedures of European standards. The modulus of elasticity mean value found in this project was $22 \%$ higher than that adopted by IRAM 9662-2 (2006) for the best strength class of sawn timber whereas it was $14 \%$ higher than that adopted by IRAM 9660-1 (2006) for the best strength class of glued laminated timber of the same species. Modulus of elasticity also exhibited in this research a mean value $22 \%$ and $53 \%$ higher, respectively, than those published for LVL manufactured from Norway spruce and Uruguayan Eucalyptus grandis. The results also confirmed the particularly high stiffness/density relation previously published for sawn and glued laminated timber of this Argentinean deciduous species. This particularity, together with the relatively low statistical variation found in this study for strength $(\mathrm{COV}=9 \%)$ and modulus of elasticity (COV $=10 \%$ ), may be considered an important advantage of this product for structural purposes and confirm that it may advantageously perform when a material of high quality is needed. The correlation between global modulus of elasticity and strength $\left(\mathrm{R}^{2}=0.37\right)$ and between density and strength $\left(\mathrm{R}^{2}=0.19\right)$ was similar to that reported for sawn timber of the same species whereas a higher correlation was found between density and global modulus of elasticity $\left(\mathrm{R}^{2}=0.67\right)$.

\section{REFERENCES}

Beall, F.C. 2007. Industrial applications and opportunities for non-destructive evaluation of structural wood members. Maderas Ciencia y tecnología 9(2):127-134.

Benites, L. 2004. Características de madera de chapas laminadas (LVL) de plantaciones de rápido crecimiento del Uruguay. Nota Técnica No 3- LATU - Sector Productos Forestales, Montevideo, 6 p.

EN 322. 1993. Wood-based panels, Determination of moisture content. CEN, Brussels.

EN 323. 1993. Wood-based panels, Determination of density. CEN, Brussels. 
EN 408. 2004. Holzbauwerke, Bauholz für tragende Zwecke und Brettschichtholz, Bestimmung einiger physikalischer und mechanischer Eigenschaften. Europäisches Komitee für Normung, Beuth Verlag, Berlin.

EN 1995-1-1. 2005. Eurocode 5: Bemessung und Konstruktion von Holzbauten - Teil 1-1: Allgemeines - Allgemeine Regeln und Regeln für den Hochbau. Deutsches Institut für Normung e. V., Beuth Verlag, Berlin.

EN 14374. 2005. Structures en bois - LVL (Lamibois). Association Française de Normalisation, France.

Glos, P. 1995. Strength grading. In: Timber Engineering STEP 1, Centrum Hout, The Netherlands, A6:(1-8).

Ilic J. 2001. Relationship among the dynamic and static elastic properties of air-dry Eucalyptus delegatensis R. Baker. Holz Roh- Werkst 59:169-175.

INTA. 1995. Manual para Productores de Eucaliptos de la Mesopotamia Argentina. Grupo Forestal, Instituto Nacional de Tecnología Agropecuaria, EEA Concordia, Argentina.

IRAM 9660-1. 2006. Madera laminada encolada estructural, Parte 1: Clases de resistencia y requisitos de fabricación y de control. Instituto Argentino de Normalización y Certificación, Buenos Aires.

IRAM 9662-2. 2006. Madera laminada encolada estructural, Clasificación visual de las tablas por resistencia, Parte 2: Tablas de Eucalyptus grandis. Instituto Argentino de Normalización y Certificación, Buenos Aires.

Piter, J.C.; Cotrina, A.D.; Sosa Zitto, M.A.; Stefani, P.M.; Torrán, E.A. 2007. Determination of characteristic strength and stiffness values in glued laminated beams of Argentinean Eucalyptus grandis according to European standards. Holz Roh-Werkst 65(4): 261-266.

Piter, J.C.; Zerbino, R. L.; Blaß, H. J. 2004a. Effectiveness of Fundamental Resonant Frequency for determining the elastic properties of Argentinean Eucalyptus grandis in structural sizes. Holz Roh-Werkst 62(2): 88-92.

Piter, J.C.; Zerbino, R.L.; Blaß, H.J. 2004b. Machine strength grading of Argentinean Eucalyptus grandis. Main grading parameters and analysis of strength profiles according to European standards. Holz Roh- Werkst 62:9-15.

Piter, J.C.; Zerbino, R.L.; Blaß, H.J. 2004c. Visual strength grading of Argentinean Eucalyptus grandis. Strength, stiffness and density profiles and corresponding limits for the main grading parameters. Holz Roh-Werkst 62(1): 1-8.

prEN 14358. 2006. Entwurf Holzbauwerke, Berechnung der $5 \%$-Quantile für charakteristische Werte und Annahmekriterien für Proben. Deutsches Institut für Normung e. V., Beuth Verlag, Berlin.

Ranta-Maunus, A. 1995. Laminated veneer lumber and other structural sections. In: Timber Engineering STEP 1, Centrum Hout, The Netherlands, A9:(1-7)

Shukla, S.R.; Kamdem, D.P. 2007. Properties of laminated veneer lumber (LVL) made with low density hardwood species: effect of the pressure duration. Holz Roh-Werkst 66:119-127. 